\title{
Combination gut hormones: prospects and questions for the future of obesity and diabetes therapy
}

\author{
Bernard Khoo' ${ }^{1}$ and Tricia Mei-Mei Tan (102 \\ 'Endocrinology, Division of Medicine, University College London, Royal Free Campus, London, UK \\ 2Department of Digestion, Metabolism and Reproduction, Imperial College London, Hammersmith Campus, London, UK
}

Correspondence should be addressed to T M-M Tan: t.tan@imperial.ac.uk

\begin{abstract}
Obesity represents an important public health challenge for the twenty-first century: globalised, highly prevalent and increasingly common with time, this condition is likely to reverse some of the hard-won gains in mortality accomplished in previous centuries. In the search for safe and effective therapies for obesity and its companion, type 2 diabetes mellitus (T2D), the gut hormone glucagon-like peptide-1 (GLP-1) has emerged as a forerunner and analogues thereof are now widely used in treatment of obesity and T2D, bringing proven benefits in improving glycaemia and weight loss and, notably, cardiovascular outcomes. However, GLP-1 alone is subject to limitations in terms of efficacy, and as a result, investigators are evaluating other gut hormones such as glucose-dependent insulinotropic peptide (GIP), glucagon and peptide YY (PYY) as possible partner hormones that may complement and enhance GLP-1's therapeutic effects. Such combination gut hormone therapies are in pharmaceutical development at present and are likely to make it to market within the next few years. This review examines the physiological basis for combination gut hormone therapy and presents the latest clinical results that underpin the excitement around these treatments. We also pose, however, some hard questions for the field which need to be answered before the full benefit of such treatments can be realised.
\end{abstract}

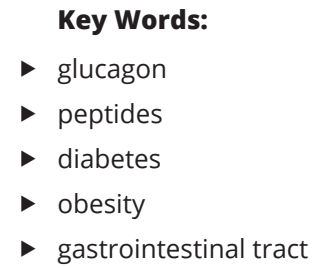

Journal of Endocrinology (2020) 246, R65-R74

\section{Introduction}

Obesity affects approximately $13 \%$ of the world's adult population with 39\% being overweight (World Health Organisation 2000). It is a multi-systemic disease state with serious co-morbidities that include cardiovascular disease, type 2 diabetes (T2D), hypertension, hyperlipidaemia, obstructive sleep apnoea, subfertility, cancers (breast, ovary, prostate, liver, endometrium and colon) and fatty liver disease/steatohepatitis leading to cirrhosis and liver failure. Key drivers of this tidal wave of obesity include poor nutrition from highly processed foods tuned to appeal to our hedonic responses, reduced or no opportunities for physical activity imposed by the physical environment and lifestyle choices, genetic factors which play a role in determining susceptibility to obesity and its complications, epigenetic factors arising from prenatal exposure to obesogenic influences and the less well-understood phenomenon of microbiotal alteration leading to increased absorption of energy from 
food and a pro-inflammatory milieu driving the metabolic imbalances and deleterious consequences of obesity (De Lorenzo et al. 2020).

Much time and money have been spent on finding effective, safe, sustainable and cost-effective treatments for obesity and its cohort T2D. Lifestyle changes focusing on weight loss via calorie restriction, even despite modest weight losses, are overall effective in reducing mortality (Ma et al. 2017) and are judged cost-effective (Avenell et al. 2018). Pharmacotherapy utilising a variety of approaches such as pancreatic lipase inhibition (orlistat), cannabinoid receptor antagonism (rimonabant), 5-HT receptor activation (fenfluramine, sibutramine, lorcaserin), sympathetic nervous system activation (phentermine, sibutramine), combined activation of appetite-regulating pro-opiomelanocortin neurones (bupropion/naltrexone) and MetAP2 inhibition (beloranib) have been modestly effective in reducing weight, but have been beset by adverse effects (Khera et al. 2016), which has led to the withdrawal of most of these treatments from development or the market. Bariatric surgery, for example, Roux-en-Y gastric bypass (RYGB) or sleeve gastrectomy, has emerged over the past four decades as the most effective treatment for obesity, with documented long-term benefits in reducing mortality (Sjöström 2013). The prospect of enforcing the remission of obesity-associated T2D with surgery (Schauer et al. 2017) has led to recommendations that this modality is considered for this condition (Rubino et al. 2016). However, the scalability of bariatric surgery is limited by the number of specialist surgeons/facilities for this surgery, the fact that some surgical candidates may not be fit enough to undertake surgery and the fact that many people remain apprehensive about taking up this option. Moreover, even though perioperative mortality is low, postoperative complications such as post-bariatric hypoglycaemia (Tharakan et al. 2017) can be extremely troublesome. Lastly, bariatric surgical procedures are 'one size fits all', where patients undergo standardised procedures, but end up with less-than-predictable results in terms of weight loss, impact on obesity-related T2D and long-term weight regain (King et al. 2019). As a result, there is still an unmet need for other approaches to the treatment of obesity and associated T2D. The gut hormones, led by GLP-1, have emerged over the past few years as a potential answer to this need. This review will discuss the rationale for combination gut hormone therapies, the latest clinical evidence underpinning these therapies, and will conclude with some important unanswered questions regarding the prospects for these therapies.

\section{GLP-1: the gut hormone path-finder}

Glucagon-like peptide 1 (GLP-1) is the most extensively studied gut hormone with translational and clinical evidence for its efficacy (Holst 2007). It is an alternatively processed product of the proglucagon peptide, secreted from neuroendocrine L-cells in the small intestine in response to nutrient ingestion. GLP-1 has pleiotropic roles, famously as an incretin hormone, stimulating glucose-dependent insulin secretion from $\beta$ cells (Drucker $\&$ Nauck 2006). Additional physiological effects include suppression of glucagon secretion from $\alpha$ cells (likely via stimulation of $\delta$ cell paracrine somatostatin secretion) (Campbell \& Drucker 2013), inhibition of gastric emptying and small bowel motility (Nauck et al. 2011), suppression of appetite and food intake leading to subsequent weight loss (Naslund et al. 2004, Bagger et al. 2015) and cardioprotective and anti-inflammatory effects (Marx \& Libby 2018). GLP-1 analogues that incorporate resistance to dipeptidyl dipeptidase-IV (DPP-IV) breakdown and other modifications that enable convenient daily or even weekly dosing are now in routine clinical use, examples being exenatide, lixisenatide, liraglutide, dulaglutide, albiglutide and semaglutide. The efficacy of these drugs in ameliorating T2D as judged by $\mathrm{HbA1c}$ has been well proven. Moreover, the glucose dependence of the insulin release occasioned by GLP-1 minimises the risks of hypoglycaemia. GLP-1 analogues are now firmly established in international treatment pathways (Buse et al. 2020). Oral GLP-1 analogues (Pratley et al. 2019) are now approved and are likely to expand the numbers of people with T2D taking this class of medications.

Given that GLP-1 analogues were associated with appreciable weight loss effects when given for T2D (Potts et al. 2015), it was natural to examine their effects when given for obesity as the primary indication, for example, the SCALE Phase 3 trials demonstrated that liraglutide at doses of $3 \mathrm{mg}$ daily led to a placebo corrected $4 \%$ mean weight loss (Pi-Sunyer et al. 2015). Greater magnitudes of weight loss were obtained in a Phase 2 trial of liraglutide's successor, semaglutide, which achieved $13.8 \%$ weight loss at the $0.4 \mathrm{mg} /$ day dose vs $11.2 \%$ with liraglutide 3 $\mathrm{mg} /$ day and $2.3 \%$ for placebo. However, this enhanced efficacy was associated with more frequent adverse events, mainly nausea, diarrhoea, constipation and vomiting (O'Neil et al. 2018).

As alluded to, GLP-1 has protective effects on the cardiovascular system, including anti-inflammation, ischaemic cardioprotection, natriuresis and diuresis, inhibition of platelet aggregation and suppression of 
post-prandial lipid excursions (Drucker 2016). These benefits have been borne out in a series of cardiovascular outcome trials in the context of T2D with established cardiovascular disease or at high risk for such disease, such as ELIXA (lixisenatide), LEADER (liraglutide), SUSTAIN-6 (semaglutide), EXSCEL (exenatide LAR), HARMONY Outcomes (albiglutide), REWIND (dulaglutide) and PIONEER-6 (oral semaglutide). As a class, these drugs reduce major adverse cardiovascular events by $12 \%$, death from cardiovascular causes by $12 \%$, fatal or non-fatal stroke by $16 \%$, fatal or non-fatal myocardial infarction by $9 \%$ and all-cause mortality by $12 \%$ and hospital admission for heart failure by $9 \%$. Moreover, the trials provide evidence for benefits for kidney disease where a composite kidney outcome (development of new-onset macroalbuminuria, a decline in estimated glomerular filtration rate/increase in serum creatinine, progression to end-stage kidney disease or death attributable to kidney causes) is reduced by $17 \%$, mainly driven by a reduction in urinary albumin excretion (Kristensen et al. 2019). GLP-1 analogues are now recommended for people with T2D who are at high risk of cardiovascular disease (Buse et al. 2020).

A post hoc analysis of the SCALE trials in people with obesity (who were not specifically selected for high risk of cardiovascular disease) has suggested that there is a reduction in cardiovascular events (hazard ratio 0.42) with high-dose liraglutide, but with wide CIs (0.17-1.08) (Davies et al. 2018). In comparison, other treatments for obesity have either demonstrated adverse cardiovascular outcomes (e.g. sibutramine) or appear to be neutral/safe in this respect (e.g. lorcaserin). Dedicated cardiovascular outcomes trials for this treatment indication are required to definitively demonstrate cardiovascular safety (and, hopefully, benefit) in this population and are forthcoming (e.g. SELECT: ClinicalTrials.gov NCT03574597).

To summarise, GLP-1 analogues are mature clinical treatments for T2D and obesity. However, at the highest doses, patients commonly experience gastrointestinal side effects, typically nausea, vomiting, alterations in bowel habit and abdominal pain, which limits the dose that can be given. Moreover, GLP-1 does not increase (or may even reduce) energy expenditure in humans (Flint et al. 2000). As a result, the magnitude of weight loss observed with GLP-1 analogues, although valuable, is limited with one in three failing to achieve a minimal 5\% weight loss even with high-dose liraglutide (Pi-Sunyer et al. 2015). As a result, investigators have considered the use of GLP-1 in combination with other gut hormones that may bring complementary benefits, and this has led to a search for suitable partners or partner activities as outlined in the following sections.

\section{GIP: twinning with GLP-1}

Glucose-dependent insulinotropic polypeptide (GIP) is the partner incretin to GLP-1. GIP is secreted by neuroendocrine $\mathrm{K}$ cells in the duodenum and jejunum in response to nutrient ingestion. GIP is thought to have a 'stabilizer' effect on glucose levels: during hyperglycaemia, GIP is insulinotropic but does not alter glucagon release, whereas during hypoglycaemia it increases glucagon release (hence increasing glucose levels) and does not affect insulin secretion (Christensen et al. 2011). At first blush, this might make GIP an ideal partner for GLP-1, but other properties of GIP make it less than desirable for the treatment of obesity and diabetes. GIP promotes lipid deposition in adipocytes in the context of obesity and T2D, possibly leading to further exacerbation of these conditions (Thondam et al. 2017). Unlike GLP-1, GIP does not reduce appetite and the combination of GLP-1 with GIP does not lead to any more significant appetite reduction than GLP-1 alone (Bergmann et al. 2019). GIP's insulinotropic actions and amelioration of glycaemia are impaired in the context of T2D. As a result, some investigators have even explored the idea of GIP antagonism as a concept for therapy (Gasbjerg et al. 2019), but the potential of this approach is not yet clear.

A ray of hope for GIP comes from the observation that, in the context of T2D, insulin therapy and normalization of glucose levels restore the favourable incretin effects of GIP (Hojberg et al. 2009), opening the possibility that a GLP-1/GIP combination (dubbed a 'twincretin') might be effective, the GLP-1 leading to normalisation of glycaemia and enabling GIP to exert its beneficial effects. Although short-term co-infusion studies of GLP-1/GIP do not show any decided advantage of the combination over GLP-1 alone (Daousi et al. 2009, Bergmann et al. 2019, Gasbjerg et al. 2019), twincretin drugs are nevertheless being pursued by the pharmaceutical industry (Finan et al. 2013). The early results from Lilly's twincretin tirzepatide have created some excitement in the area. Tirzepatide is a unimolecular agonist of GLP-1 and GIP with a deliberate bias towards GIP over GLP-1 activity (Coskun et al. 2018). When tested in Phase 2 in people with T2D and obesity, tirzepatide appears to have significantly superior effects on glycaemia and weight loss in comparison to the benchmark GLP-1 analogue dulaglutide, although this seems to occur at the expense of more gastrointestinal 
side effects (Frias et al. 2018). Novo Nordisk's twincretin, NNC0090-2746, has more balanced GLP-1 and GIP activity, and early clinical trials of this analogue have shown improvements in HbA1c and weight over placebo when given over 12 weeks of treatment, although the performance of NNC0090-2746 did not appear markedly better than the benchmark GLP-1 analogue liraglutide (Frias et al. 2017).

To summarise, it is currently difficult to reconcile the superior efficacy reported from the tirzepatide trials with the failure to show any substantive enhancement of physiological effects with the co-infusion of GLP-1 and GIP. Nevertheless, if the currently published data from tirzepatide is borne out in larger clinical trials, this is quite a promising prospect for therapy.

\section{Proglucagon peptides working side by side: GLP-1/glucagon agonism}

Glucagon is the metabolic hormone generated by the canonical processing of proglucagon in the alpha cells that classically antagonises the actions of insulin, by stimulating the catabolism of glycogen and gluconeogenesis to release glucose, and of fat deposits to release fatty acids for $\beta$-oxidation and hepatic ketogenesis. Less-appreciated effects of glucagon include insulinotropy, appetite suppression and increases in energy expenditure. Moreover, glucagon increases hepatic fat oxidation and represents an approach in ameliorating fatty liver disease (Finan et al. 2020). These observations suggest that glucagon may be a complementary partner for GLP-1 by improving weight loss through synergistic suppression of appetite and increased energy expenditure, and proof-of-concept physiological studies by our group have confirmed this (Tan et al. 2013, Cegla et al. 2014). However, glucagon has the undesired effect of provoking hyperglycaemia (Scott \& Bloom 2018). Our studies showed that GLP-1 contributes to this partnership by ameliorating the hyperglycaemia provoked by glucagon (Tan et al. 2013, Cegla et al. 2014).

A natural unimolecular GLP-1/glucagon dual agonist exists in the shape of oxyntomodulin, a 37 amino acid peptide that is co-secreted with GLP-1 from the L-cells of the small intestine as an additional product of the differential processing of proglucagon in the gut (Holst et al. 2018). Oxyntomodulin reduces food intake and increases energy expenditure, leading to significant weight loss in a 28-day clinical study in human volunteers (Wynne et al. 2006), and has been shown to improve insulin secretion in short-term clinical studies in people with diabetes (Shankar et al. 2018).

As a result of this promising data, GLP-1/glucagon dual agonists are under active development (Fig. 1). Cotadutide is an example of a balanced unimolecular dual agonist with equivalent GLP-1 and glucagon activities which has been shown in Phase 2 trials in people with obesity and T2D to significantly improve glycaemic tolerance to a meal stimulus and to reduce body weight by $2-3 \mathrm{~kg}$ in comparison to placebo (Ambery et al. 2018, Parker et al. 2020). Another dual agonist, SAR425899, has been shown in Phase 1 trials to reduce HbA1c by up to $0.75 \%$ in the context of T2D and body weight by up to $5 \mathrm{~kg}$ or so (Tillner et al. 2019).

In summary, GLP-1/glucagon dual agonists are promising candidates for the treatment of T2D and obesity. However, we await definitive data to establish whether these dual agonists are superior to GLP-1 analogues. Glucagon's hyperglycaemic activity might reverse some of the signal improvements in glycaemia seen with GLP-1 alone, and this may make these dual agonists less suitable for clinical situations characterised by more marked dysglycaemia.

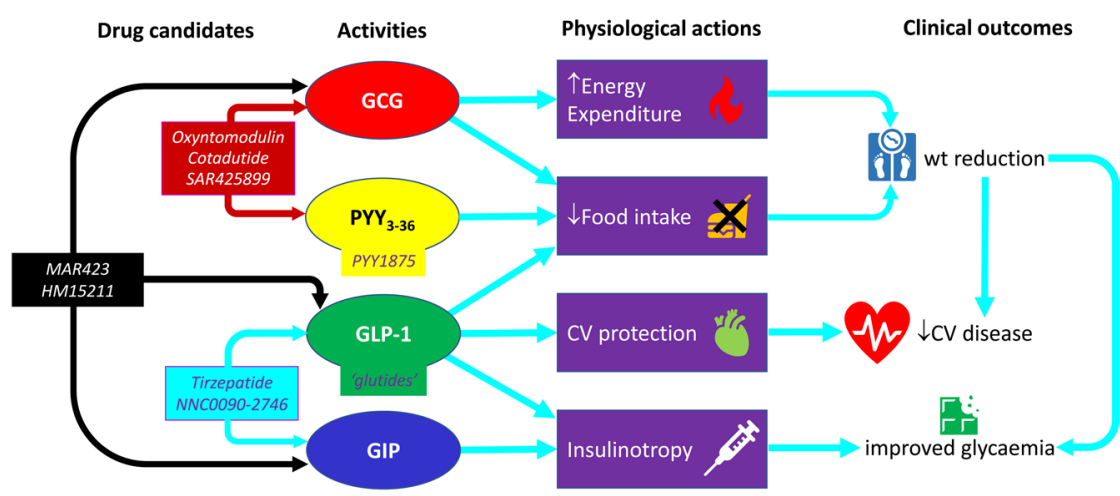

Figure 1

Schematic figure showing the relationship between combination gut hormone drug candidates, the hormonal activities stimulated, their physiological actions and the envisaged clinical outcomes. GCG, glucagon; PYY, peptide YY; GLP-1, glucagon-like peptide-1; GIP, glucosedependent insulinotropic peptide; $\mathrm{CV}$, cardiovascular. 


\section{Peptide YY: walking the straight and narrow}

Peptide YY (PYY) is another gut hormone that is co-secreted from the L cells with GLP-1 and oxyntomodulin. It exists in two major forms: the full length PYY(1-36) peptide that binds to the neuropeptide $\mathrm{Y} 1, \mathrm{Y} 2, \mathrm{Y} 4$ and $\mathrm{Y} 5$ receptors and the PYY(3-36) peptide which is derived from PYY(1-36) via processing by DPP-IV, this binds to the neuropeptide Y2 and Y5 receptors. PYY(3-36)'s chief action of interest for obesity therapy is appetite suppression, which is mediated by Y2 receptors in the arcuate nucleus, and infusion of PYY(3-36) in human volunteers induces a $33 \%$ reduction in food intake over $24 \mathrm{~h}$ (Batterham et al. 2002). Early clinical studies utilising a nasal preparation of PYY(3-36) showed, however, that the efficacy in terms of weight loss was limited by dose-dependent nausea and vomiting (Gantz et al. 2007), because of a rapid 'burst' release of PYY to supraphysiological levels. When PYY levels are increased slowly to physiological levels, suppression of food intake is obtained with better tolerability and less nausea (Batterham et al. 2002). This narrow therapeutic range means that slower release profiles are necessary to mitigate nausea and vomiting (Rangwala et al. 2019) and to enable weekly delivery of treatment, for example, Novo Nordisk's PYY1875 (Novo Nordisk 2019).

In infusion studies, the combination of PYY(3-36) and GLP-1 confers better appetite suppression than each individual peptide (Neary et al. 2005). The neurophysiological basis of this phenomenon has been investigated using blood oxygen level dependent (BOLD) functional MRI imaging studies. These show that brain areas implicated in appetite and interest in food are activated when subjects are shown pictures of food. PYY(3-36) and GLP-1 given individually reduce the activation of these areas. The co-infusion of PYY(3-36) and GLP-1 led to a synergistic effect with near-suppression of these areas, correlating with the suppression in appetite as assessed by food-intake studies (De Silva et al. 2011). Co-administration of PYY(3-36) and oxyntomodulin had also an enhanced appetite suppression compared to each peptide alone (Field et al. 2010). However, in contrast to GLP-1, PYY does not seem to have a marked effect on glucose-stimulated insulin secretion when given to human volunteers. Moreover, PYY does not add to the insulinotropic effect of GLP-1 (Tan et al. 2014). Therefore, there is ample physiological data to substantiate the added value of PYY(3-36) in terms of appetite suppression and improving weight loss, but PYY(3-36) may not have any immediately added value on glycaemia in the context of diabetes, although with enhanced weight loss, PYY(3-36) may contribute in the longer term.

Considering these factors, the likelihood is that PYY analogues will be employed in combination with GLP-1 to enhance the weight loss with GLP-1 analogues alone (Fig. 1). However, there is currently a relative paucity of published clinical studies with this class of agents to substantiate their efficacy and tolerability when given long term.

\section{Triagonism: is three better than two?}

By blending three complementary gut hormone actions, we may be able to obtain advantages over dual agonism. Surgery, and in particular RYGB, exerts many of its beneficial effects by activating the exaggerated release of GLP-1, oxyntomodulin and peptide YY after eating, leading to improvements in glucose metabolism, suppression of appetite and reductions in body weight (le Roux et al. 2007, Abdeen \& le Roux 2016). Building on this observation, we used a s.c. infusion pump to deliver a combination of GLP-1/oxyntomodulin/PYY(3-36) (GOP) at doses to replicate the elevated post-prandial levels found after RYGB (Tan et al. 2017). When this GOP combination was given for up to $12 \mathrm{~h}$ per day for 28 days in obese people with $\mathrm{T} 2 \mathrm{D}$ or prediabetes, we showed that GOP infusion achieves superior glucose tolerance and reduced glucose variability compared with RYGB and has a favourable effect on body weight, although energy expenditure was not enhanced, at least with the doses used (Behary et al. 2019). Our proof-of-concept study suggests that triple agonism of the GLP-1, glucagon and Y2 receptors using the GOP combination may possess advantages even over RYGB, hitherto considered the standard of care for treatment of obesity and diabetes, and further studies are planned to explore the doses and combinations to obtain optimal efficacies and to substantiate the concept.

Other groups have explored the concept of GLP-1/GIP/glucagon triagonism to obtain extra benefits from adding the benefits of glucagon action (promotion of energy expenditure and amelioration of fatty liver disease) to the 'twincretin' effects of GLP-1 and GIP (Fig. 1). These properties were combined in the design of the unimolecular triagonist MAR423 with promising results in animal models which have been taken forward to an ongoing Phase 1 trial (Brandt et al. 2018). HM15211 is another triagonist compound which has shown favourable pre-clinical data in animal models of 
steatohepatitis (Finan et al. 2015, Tschop et al. 2016, Jall et al. 2017) and which is currently in Phase 1 trials.

\section{Some questions for the future}

\section{What are the optimal combinations and doses of gut hormone activities?}

The combination approach brings complications in terms of selecting the optimal balance of receptor agonistic activities. Animal models are helpful in the pre-clinical selection of this balance for development (Day et al. 2009), but it must be borne in mind that these models do not completely replicate the human physiological situation: for example, GLP-1 increases energy expenditure in rodents, but not in humans. Therefore, pre-clinical data on drug candidates should be interpreted with caution. Further long-term physiological clinical studies are required to define the balance of receptor agonism that leads to optimal outcomes.

\section{Will combination therapies inherit the favourable effects on clinical outcomes demonstrated by GLP-1 analogues?}

Although the scientific and clinical evidence for GLP-1's benefits on clinically valuable endpoints such as cardiovascular and renal disease in the context of T2D is reasonably developed, such evidence is lacking in the context of obesity treatment and is currently lacking for any of the combination analogues. Moreover, the effects of the combination partner activities may be undesirable: for example, GIP may carry pro-inflammatory and pro-atherosclerotic effects (Heimburger et al. 2020). Assuming the new combination gut hormone therapies do deliver enhanced weight loss and glycaemic control in forthcoming Phase III trials, it will be crucial to see if the beneficial effects of GLP-1 over-ride any potential undesirable effects from partner hormone activities.

\section{Is a unimolecular agonist the correct approach or do individuals require customised balancing of activities?}

Many of the developmentally advanced dual analogues (e.g. tirzepatide and cotadutide) have been unimolecular analogues which have modified a basic gut hormone sequence to add in or enhance receptor activity, arriving at a specified balance of activities for each drug.
Although this approach makes development simpler, this approach assumes that one balance will fit all. Clinical experience with GLP-1 analogues shows that there is a considerable intra-individual variation in response to dosing, for example, in terms of weight loss and tolerability (Pi-Sunyer et al. 2015), and logically, there will be a variation of response to the relative balance of hormone activities with dual or triple agonists. To obtain a truly optimal response on multidimensional outcomes (weight loss, glycaemia, cardiovascular protection, long-term tolerability etc.) that meet customised goals, individuals may require customised balancing of activities; however, the technical, practical and regulatory hurdles to such an approach are more difficult to surmount than the welltrodden path of unimolecular analogue development.

\section{What is the cost-effectiveness and sustainability of gut hormone analogue therapy?}

Bariatric surgery, for all its shortcomings, is accepted as cost-effective, as are lifestyle interventions (Gulliford et al. 2017, Avenell et al. 2018). The institution responsible for cost-effectiveness assessment in the United Kingdom, the National Institute for Health and Care Excellence (NICE), has assessed the cost-effectiveness of GLP-1 analogues in the treatment of $\mathrm{T} 2 \mathrm{D}$ and these are now recommended (National Institute for Health and Care Excellence 2015). On the other hand, liraglutide $3 \mathrm{mg}$ for the obesity indication has not yet been recommended by NICE, as of writing, primarily because cost-effectiveness estimates range up to $£ 105,000$ per quality-adjusted life year (QALY), much higher than the acceptable limit of $£ 20,000$ to $£ 30,000$ per QALY (National Institute for Health and Care Excellence 2020). One key driver of this uncertainty over the cost-effectiveness is how long analogue therapy will be given beyond a treatment length of 2 years and another is the paucity of direct evidence for cardiovascular benefit when liraglutide is employed in this context. These uncertainties, as well as a sustainable pricing model, will need to be resolved to enable those who need it to access treatment.

\section{What is the place of gut hormone analogue treatment in the journey of people with obesity?}

To date, the trials of GLP-1 analogues have mostly concentrated on demonstrating their efficacy and safety on a baseline of diet and exercise advice delivered in a clinical trial context. Some trials have demonstrated that analogues have an added value on top of a lifestyle 
intervention, for example, the SCALE-Maintenance trial showed that liraglutide $3 \mathrm{mg}$ could induce a mean weight loss of $6 \%$ on top of a weight loss of $6 \%$ induced by a run-in low calorie diet (Wadden et al. 2013). However, it is currently unclear whether an analogue is best employed as an induction therapy followed by maintenance with lifestyle change vs induction with lifestyle change followed by analogue therapy. There is also uncertainty as to how long analogue treatment should last: discontinuation of liraglutide after 56 weeks of treatment leads to an upwards drift in weight (Wadden et al. 2013), and there is no clear guidance as to whether analogue therapy should continue for longer. Gut hormone treatment cannot be regarded as a 'silver bullet' for obesity and T2D, rather they will have a place within a personalised and integrated programme for weight and metabolic management that incorporates lifestyle, dietary change as well as psychological support and an element of coaching. Pragmatic trials to understand the best sequence to employ these management tools within such a framework are sorely needed.

\section{Conclusion}

Combination gut hormone drugs utilising GLP-1 as the mainstay are likely to appear as marketed therapies for T2D and obesity within the forthcoming decade, and there is a real prospect of these medications delivering improved weight loss and glycaemic control over presently available analogues (Fig. 1). Many questions remain, however, as to what the right combination is, how they work and how best to employ these new medications. To answer these questions, the pharmaceutical and scientific communities will need to gather evidence from a wide range of studies ranging from long-term physiological studies to randomised controlled trials and, crucially, pragmatic trials of treatment models to bridge the gap between Phase 3 study and real-life practice. Only then will we be able to realise the full potential of gut hormone therapy.

\section{Declaration of interest}

The authors declare that there is no conflict of interest that could be perceived as prejudicing the impartiality of this review.

\section{Funding}

This article presents independent research funded by the UK National Institute for Health Research (NIHR) and supported by the NIHR Clinical Research Facility (CRF) and Biomedical Research Centre (BRC) at Imperial
College Healthcare NHS Trust. The views expressed are those of the author(s) and not necessarily those of the NHS, the NIHR or the Department of Health. The Department of Digestion, Metabolism and Reproduction is funded by grants from the MRC, BBSRC, NIHR, an Integrative Mammalian Biology (IMB) Capacity Building Award, an FP7-HEALTH-2009-241592 EuroCHIP grant and is supported by the NIHR Biomedical Research Centre Funding Scheme. TT is funded by the NIHR, NIHR BRC and the Moulton Charitable Research Foundation. BK is funded by the Moulton Charitable Research Foundation.

\section{References}

Abdeen G \& le Roux CW 2016 Mechanism underlying the weight loss and complications of Roux-en-Y gastric bypass. Review. Obesity Surgery 26 410-421. (https://doi.org/10.1007/s11695-015-1945-7)

Ambery P, Parker VE, Stumvoll M, Posch MG, Heise T, Plum-Moerschel L, Tsai LF, Robertson D, Jain M, Petrone M, et al. 2018 MEDI 0382, A GLP-1 and glucagon receptor dual agonist, in obese or overweight patients with type 2 diabetes: a randomised, controlled, double-blind, ascending dose and phase 2a study. Lancet 391 2607-2618. (https:// doi.org/10.1016/S0140-6736(18)30726-8)

Avenell A, Robertson C, Skea Z, Jacobsen E, Boyers D, Cooper D, Aceves-Martins M, Retat L, Fraser C, Aveyard P, et al. 2018 Bariatric surgery, lifestyle interventions and orlistat for severe obesity: the REBALANCE mixed-methods systematic review and economic evaluation. Health Technology Assessment 22 1-246. (https://doi. org/10.3310/hta22680)

Bagger JI, Holst JJ, Hartmann B, Andersen B, Knop FK \& Vilsboll T 2015 Effect of oxyntomodulin, glucagon, GLP-1, and combined glucagon + GLP-1 infusion on food intake, appetite, and resting energy expenditure. Journal of Clinical Endocrinology and Metabolism 100 4541-4552. (https://doi.org/10.1210/jc.2015-2335)

Batterham RL, Cowley MA, Small CJ, Herzog H, Cohen MA, Dakin CL, Wren AM, Brynes AE, Low MJ, Ghatei MA, et al. 2002 Gut hormone PYY(3-36) physiologically inhibits food intake. Nature 418 650-654. (https://doi.org/10.1038/nature00887)

Behary P, Tharakan G, Alexiadou K, Johnson N, Wewer Albrechtsen NJ, Kenkre J, Cuenco J, Hope D, Anyiam O, Choudhury S, et al. 2019 Combined GLP-1, oxyntomodulin, and peptide YY improves body weight and glycemia in obesity and prediabetes/type 2 diabetes: a randomized, single-blinded, placebo-controlled study. Diabetes Care 42 1446-1453. (https://doi.org/10.2337/dc19-0449)

Bergmann NC, Lund A, Gasbjerg LS, Meessen ECE, Andersen MM, Bergmann S, Hartmann B, Holst JJ, Jessen L, Christensen MB, et al. 2019 Effects of combined GIP and GLP-1 infusion on energy intake, appetite and energy expenditure in overweight/obese individuals: a randomised, crossover study. Diabetologia 62 665-675. (https://doi. org/10.1007/s00125-018-4810-0)

Brandt SJ, Gotz A, Tschop MH \& Muller TD 2018 Gut hormone polyagonists for the treatment of type 2 diabetes. Peptides 100 190-201. (https://doi.org/10.1016/j.peptides.2017.12.021)

Buse JB, Wexler DJ, Tsapas A, Rossing P, Mingrone G, Mathieu C, D'Alessio DA \& Davies MJ 20202019 Update to: management of hyperglycaemia in type 2 diabetes, 2018. A consensus report by the American Diabetes Association (ADA) and the European Association for the Study of Diabetes (EASD). Diabetologia 63 221-228. (https:// doi.org/10.1007/s00125-019-05039-w)

Campbell JE \& Drucker DJ 2013 Pharmacology, physiology, and mechanisms of incretin hormone action. Cell Metabolism 17 819-837. (https://doi.org/10.1016/j.cmet.2013.04.008)

Cegla J, Troke RC, Jones B, Tharakan G, Kenkre J, McCullough KA, Lim CT, Parvizi N, Hussein M, Chambers ES, et al. 2014 Coinfusion of low-dose GLP-1 and glucagon in man results in a reduction in food intake. Diabetes 63 3711-3720. (https://doi.org/10.2337/db14-0242) https://joe.bioscientifica.com

https://doi.org/10.1530/JOE-20-0119 (c) 2020 Society for Endocrinology Published by Bioscientifica Ltd. Printed in Great Britain 
Christensen M, Vedtofte L, Holst JJ, Vilsboll T \& Knop FK 2011 Glucosedependent insulinotropic polypeptide: a bifunctional glucosedependent regulator of glucagon and insulin secretion in humans. Diabetes 60 3103-3109. (https://doi.org/10.2337/db11-0979)

Coskun T, Sloop KW, Loghin C, Alsina-Fernandez J, Urva S, Bokvist KB, Cui X, Briere DA, Cabrera O, Roell WC, et al. 2018 LY3298176, a novel dual GIP and GLP-1 receptor agonist for the treatment of type 2 diabetes mellitus: from discovery to clinical proof of concept. Molecular Metabolism 18 3-14. (https://doi.org/10.1016/j. molmet.2018.09.009)

Daousi C, Wilding JP, Aditya S, Durham BH, Cleator J, Pinkney JH \& Ranganath LR 2009 Effects of peripheral administration of synthetic human glucose-dependent insulinotropic peptide (GIP) on energy expenditure and subjective appetite sensations in healthy normal weight subjects and obese patients with type 2 diabetes. Clinical Endocrinology 71 195-201. (https://doi.org/10.1111/j.13652265.2008.03451.x)

Davies MJ, Aronne LJ, Caterson ID, Thomsen AB, Jacobsen PB, Marso SP \& Satiety and Clinical Adiposity - Liraglutide Evidence in individuals with and without diabetes (SCALE) study groups 2018 Liraglutide and cardiovascular outcomes in adults with overweight or obesity: a post hoc analysis from SCALE randomized controlled trials. Diabetes, Obesity and Metabolism 20 734-739. (https://doi.org/10.1111/ dom.13125)

Day JW, Ottaway N, Patterson JT, Gelfanov V, Smiley D, Gidda J, Findeisen H, Bruemmer D, Drucker DJ, Chaudhary N, et al. 2009 A new glucagon and GLP-1 co-agonist eliminates obesity in rodents. Nature Chemical Biology 5 749-757. (https://doi.org/10.1038/ nchembio.209)

De Lorenzo A, Romano L, Di Renzo L, Di Lorenzo N, Cenname G \& Gualtieri P 2020 Obesity: a preventable, treatable, but relapsing disease. Nutrition 71 110615. (https://doi.org/10.1016/j. nut.2019.110615)

De Silva A, Salem V, Long CJ, Makwana A, Newbould RD, Rabiner EA, Ghatei MA, Bloom SR, Matthews PM, Beaver JD, et al. 2011 The gut hormones PYY 3-36 and GLP-1 7-36 amide reduce food intake and modulate brain activity in appetite centers in humans. Cell Metabolism 14 700-706. (https://doi.org/10.1016/j.cmet.2011.09.010)

Drucker DJ 2016 The cardiovascular biology of glucagon-like peptide-1. Cell Metabolism 24 15-30. (https://doi.org/10.1016/j. cmet.2016.06.009)

Drucker DJ \& Nauck MA 2006 The incretin system: glucagon-like peptide-1 receptor agonists and dipeptidyl peptidase- 4 inhibitors in type 2 diabetes. Lancet 368 1696-1705. (https://doi.org/10.1016/ S0140-6736(06)69705-5)

Field BC, Wren AM, Peters V, Baynes KC, Martin NM, Patterson M, Alsaraf S, Amber V, Wynne K, Ghatei MA, et al. 2010 PYY3-36 and oxyntomodulin can be additive in their effect on food intake in overweight and obese humans. Diabetes 59 1635-1639. (https://doi. org/10.2337/db09-1859)

Finan B, Ma T, Ottaway N, Muller TD, Habegger KM, Heppner KM, Kirchner H, Holland J, Hembree J, Raver C, et al. 2013 Unimolecular dual incretins maximize metabolic benefits in rodents, monkeys, and humans. Science Translational Medicine 5 209ra151. (https://doi. org/10.1126/scitranslmed.3007218)

Finan B, Yang B, Ottaway N, Smiley DL, Ma T, Clemmensen C, Chabenne J, Zhang L, Habegger KM, Fischer K, et al. 2015 A rationally designed monomeric peptide triagonist corrects obesity and diabetes in rodents. Nature Medicine 21 27-36. (https://doi.org/10.1038/ nm.3761)

Finan B, Capozzi ME \& Campbell JE 2020 Repositioning glucagon action in the physiology and pharmacology of diabetes. Diabetes 69 532-541. (https://doi.org/10.2337/dbi19-0004)

Flint A, Raben A, Rehfeld JF, Holst JJ \& Astrup A 2000 The effect of glucagon-like peptide-1 on energy expenditure and substrate metabolism in humans. International Journal of Obesity and
Related Metabolic Disorders 24 288-298. (https://doi.org/10.1038/ sj.ijo.0801126)

Frias JP, Bastyr 3rd EJ, Vignati L, Tschop MH, Schmitt C, Owen K, Christensen RH \& DiMarchi RD 2017 The sustained effects of a dual GIP/GLP-1 receptor agonist, NNC0090-2746, in patients with type 2 diabetes. Cell Metabolism 26 343.e2-352.e2. (https://doi.org/10.1016/j. cmet.2017.07.011)

Frias JP, Nauck MA, Van J, Kutner ME, Cui X, Benson C, Urva S, Gimeno RE, Milicevic Z, Robins D, et al. 2018 Efficacy and safety of LY3298176, a novel dual GIP and GLP-1 receptor agonist, in patients with type 2 diabetes: a randomised, placebo-controlled and active comparator-controlled phase 2 trial. Lancet 392 2180-2193. (https:// doi.org/10.1016/S0140-6736(18)32260-8)

Gantz I, Erondu N, Mallick M, Musser B, Krishna R, Tanaka WK, Snyder K, Stevens C, Stroh MA, Zhu H, et al. 2007 Efficacy and safety of intranasal peptide YY3-36 for weight reduction in obese adults. Journal of Clinical Endocrinology and Metabolism 92 1754-1757. (https://doi.org/10.1210/jc.2006-1806)

Gasbjerg LS, Christensen MB, Hartmann B, Lanng AR, Sparre-Ulrich AH, Gabe MBN, Dela F, Vilsboll T, Holst JJ, Rosenkilde MM, et al. 2018 GIP(3-30)NH2 is an efficacious GIP receptor antagonist in humans: a randomised, double-blinded, placebo-controlled, crossover study. Diabetologia 61 413-423. (https://doi.org/10.1007/s00125-017-4447-4)

Gasbjerg LS, Helsted MM, Hartmann B, Jensen MH, Gabe MBN, SparreUlrich AH, Veedfald S, Stensen S, Lanng AR, Bergmann NC, et al. 2019 Separate and combined glucometabolic effects of endogenous glucose-dependent insulinotropic polypeptide and glucagon-like peptide 1 in healthy individuals. Diabetes 68 906-917. (https://doi. org/10.2337/db18-1123)

Gulliford MC, Charlton J, Prevost T, Booth H, Fildes A, Ashworth M, Littlejohns P, Reddy M, Khan O \& Rudisill C 2017 Costs and outcomes of increasing access to bariatric surgery: cohort study and cost-effectiveness analysis using electronic health records. Value in Health 20 85-92. (https://doi.org/10.1016/j.jval.2016.08.734)

Heimburger SM, Bergmann NC, Augustin R, Gasbjerg LS, Christensen MB \& Knop FK 2020 Glucose-dependent insulinotropic polypeptide (GIP) and cardiovascular disease. Peptides 125 170174. (https://doi. org/10.1016/j.peptides.2019.170174)

Hojberg PV, Vilsboll T, Rabol R, Knop FK, Bache M, Krarup T, Holst JJ \& Madsbad S 2009 Four weeks of near-normalisation of blood glucose improves the insulin response to glucagon-like peptide- 1 and glucose-dependent insulinotropic polypeptide in patients with type 2 diabetes. Diabetologia 52 199-207. (https://doi.org/10.1007/s00125008-1195-5)

Holst JJ 2007 The physiology of glucagon-like peptide 1. Physiological Reviews 87 1409-1439. (https://doi.org/10.1152/physrev.00034.2006)

Holst JJ, Albrechtsen NJW, Gabe MBN \& Rosenkilde MM 2018 Oxyntomodulin: actions and role in diabetes. Peptides 100 48-53. (https://doi.org/10.1016/j.peptides.2017.09.018)

Jall S, Sachs S, Clemmensen C, Finan B, Neff F, DiMarchi RD, Tschop MH, Muller TD \& Hofmann SM 2017 Monomeric GLP-1/GIP/glucagon triagonism corrects obesity, hepatosteatosis, and dyslipidemia in female mice. Molecular Metabolism 6 440-446. (https://doi. org/10.1016/j.molmet.2017.02.002)

Khera R, Murad MH, Chandar AK, Dulai PS, Wang Z, Prokop LJ, Loomba R, Camilleri M \& Singh S 2016 Association of pharmacological treatments for obesity with weight loss and adverse events: a systematic review and meta-analysis. JAMA 315 2424-2434 (https://doi.org/10.1001/jama.2016.7602)

King WC, Belle SH, Hinerman AS, Mitchell JE, Steffen KJ \& Courcoulas AP 2019 Patient behaviors and characteristics related to weight regain after Roux-en-Y gastric bypass: a multicenter prospective cohort study. Annals of Surgery [epub]. (https://doi.org/10.1097/ SLA.0000000000003281)

Kristensen SL, Rorth R, Jhund PS, Docherty KF, Sattar N, Preiss D, Kober L, Petrie MC \& McMurray JJV 2019 Cardiovascular, mortality, and https://joe.bioscientifica.com https://doi.org/10.1530/JOE-20-0119
(C) 2020 Society for Endocrinology Published by Bioscientifica Ltd. Printed in Great Britain 
kidney outcomes with GLP-1 receptor agonists in patients with type 2 diabetes: a systematic review and meta-analysis of cardiovascular outcome trials. Lancet: Diabetes and Endocrinology 7 776-785. (https:// doi.org/10.1016/S2213-8587(19)30249-9)

le Roux CW, Welbourn R, Werling M, Osborne A, Kokkinos A, Laurenius A, Lonroth H, Fandriks L, Ghatei MA, Bloom SR, et al. 2007 Gut hormones as mediators of appetite and weight loss after Roux-en-Y gastric bypass. Annals of Surgery 246 780-785. (https://doi. org/10.1097/SLA.0b013e3180caa3e3)

Ma C, Avenell A, Bolland M, Hudson J, Stewart F, Robertson C, Sharma P, Fraser C \& MacLennan G 2017 Effects of weight loss interventions for adults who are obese on mortality, cardiovascular disease, and cancer: systematic review and meta-analysis. BMJ 359 j4849. (https://doi. org/10.1136/bmj.j4849)

Marx N \& Libby P 2018 Cardiovascular benefits of GLP-1 receptor agonism: is inflammation a key? JACC: Basic to Translational Science $\mathbf{3}$ 858-860. (https://doi.org/10.1016/j.jacbts.2018.11.008)

Naslund E, King N, Mansten S, Adner N, Holst JJ, Gutniak M \& Hellstrom PM 2004 Prandial subcutaneous injections of glucagon-like peptide-1 cause weight loss in obese human subjects. British Journal of Nutrition 91 439-446. (https://doi.org/10.1079/BJN20031064)

National Institute for Health and Care Excellence 2015 Type 2 diabetes in adults: management. London, UK: NICE. (available at: https://www. nice.org.uk/guidance/ng28)

National Institute for Health and Care Excellence 2020 Liraglutide for managing overweight and obesity [ID740] - guideline in development. London, UK: NICE. (available at: https://www.nice.org. uk/guidance/indevelopment/gid-ta10388)

Nauck MA, Kemmeries G, Holst JJ \& Meier JJ 2011 Rapid tachyphylaxis of the glucagon-like peptide 1-induced deceleration of gastric emptying in humans. Diabetes 60 1561-1565. (https://doi.org/10.2337/db10-0474)

Neary NM, Small CJ, Druce MR, Park AJ, Ellis SM, Semjonous NM, Dakin CL, Filipsson K, Wang F, Kent AS, et al. 2005 Peptide YY336 and glucagon-like peptide-17-36 inhibit food intake additively. Endocrinology 146 5120-5127. (https://doi.org/10.1210/en.2005-0237)

Novo Nordisk 2019 Annual report. Bagsværd, Denmark: Novo Nordisk. (available at: https://www.novonordisk.com/content/dam/Denmark/ HQ/investors/irmaterial/annual_report/2020/Novo-Nordisk-AnnualReport-2019.pdf)

O'Neil PM, Birkenfeld AL, McGowan B, Mosenzon O, Pedersen SD, Wharton S, Carson CG, Jepsen CH, Kabisch M \& Wilding JPH 2018 Efficacy and safety of semaglutide compared with liraglutide and placebo for weight loss in patients with obesity: a randomised, doubleblind, placebo and active controlled, dose-ranging, phase 2 trial. Lancet 392 637-649. (https://doi.org/10.1016/S0140-6736(18)31773-2)

Parker VER, Robertson D, Wang T, Hornigold DC, Petrone M, Cooper AT, Posch MG, Heise T, Plum-Moerschel L, Schlichthaar H, et al. 2020 Efficacy, safety, and mechanistic insights of cotadutide, a dual receptor glucagon-like peptide-1 and glucagon agonist. Journal of Clinical Endocrinology and Metabolism 105 803-820. (https://doi. org/10.1210/clinem/dgz047)

Pi-Sunyer X, Astrup A, Fujioka K, Greenway F, Halpern A, Krempf M, Lau DC, le Roux CW, Violante Ortiz R, Jensen CB, et al. 2015 A randomized, controlled trial of $3.0 \mathrm{mg}$ of liraglutide in weight management. New England Journal of Medicine 373 11-22. (https://doi. org/10.1056/NEJMoa1411892)

Potts JE, Gray LJ, Brady EM, Khunti K, Davies MJ \& Bodicoat DH 2015 The effect of glucagon-like peptide 1 receptor agonists on weight loss in type 2 diabetes: a systematic review and mixed treatment comparison meta-analysis. PLOS ONE 10 e0126769. (https://doi. org/10.1371/journal.pone.0126769)

Pratley R, Amod A, Hoff ST, Kadowaki T, Lingvay I, Nauck M, Pedersen KB, Saugstrup T, Meier JJ \& PIONEER 4 Investigators 2019 Oral semaglutide versus subcutaneous liraglutide and placebo in type 2 diabetes (PIONEER 4): a randomised, double-blind, phase 3a trial. Lancet 394 39-50. (https://doi.org/10.1016/S01406736(19)31271-1)

Rangwala SM, D'Aquino K, Zhang YM, Bader L, Edwards W, Zheng S, Eckardt A, Lacombe A, Pick R, Moreno V, et al. 2019 A long-acting PYY3-36 analog mediates robust anorectic efficacy with minimal emesis in nonhuman Primates. Cell Metabolism 29 837.e5-843.e5. (https://doi.org/10.1016/j.cmet.2019.01.017)

Rubino F, Nathan DM, Eckel RH, Schauer PR, Alberti KG, Zimmet PZ, Del Prato S, Ji L, Sadikot SM, Herman WH, et al. 2016 Metabolic surgery in the treatment algorithm for type 2 diabetes: a joint statement by international diabetes organizations. Diabetes Care 39 861-877. (https://doi.org/10.2337/dc16-0236)

Schauer PR, Bhatt DL, Kirwan JP, Wolski K, Aminian A, Brethauer SA, Navaneethan SD, Singh RP, Pothier CE, Nissen SE, et al. 2017 Bariatric surgery versus intensive medical therapy for diabetes - 5-year outcomes. New England Journal of Medicine 376 641-651. (https://doi. org/10.1056/NEJMoa1600869)

Scott RV \& Bloom SR 2018 Problem or solution: the strange story of glucagon. Peptides 100 36-41. (https://doi.org/10.1016/j. peptides.2017.11.013)

Shankar SS, Shankar RR, Mixson LA, Miller DL, Pramanik B, O'Dowd AK, Williams DM, Frederick CB, Beals CR, Stoch SA, et al. 2018 Native oxyntomodulin has significant glucoregulatory effects independent of weight loss in obese humans with and without type 2 diabetes. Diabetes 67 1105-1112. (https://doi.org/10.2337/db17-1331)

Sjöström L 2013 Review of the key results from the Swedish Obese Subjects (SOS) trial - a prospective controlled intervention study of bariatric surgery. Journal of Internal Medicine 273 219-234. (https:// doi.org/10.1111/joim.12012)

Tan TM, Field BC, McCullough KA, Troke RC, Chambers ES, Salem V, Gonzalez Maffe J, Baynes KC, De Silva A, Viardot A, et al. 2013 Coadministration of glucagon-like peptide-1 during glucagon infusion in humans results in increased energy expenditure and amelioration of hyperglycemia. Diabetes 62 1131-1138. (https://doi. org/10.2337/db12-0797)

Tan TM, Salem V, Troke RC, Alsafi A, Field BC, De Silva A, Misra S, Baynes KC, Donaldson M, Minnion J, et al. 2014 Combination of peptide YY3-36 with GLP-1(7-36) amide causes an increase in first-phase insulin secretion after IV glucose. Journal of Clinical Endocrinology and Metabolism 99 E2317-E2324. (https://doi. org/10.1210/jc.2014-2143)

Tan T, Behary P, Tharakan G, Minnion J, Al-Najim W, Albrechtsen NJW, Holst JJ \& Bloom SR 2017 The effect of a subcutaneous infusion of GLP-1, OXM, and PYY on energy intake and expenditure in obese volunteers. Journal of Clinical Endocrinology and Metabolism 102 2364-2372. (https://doi.org/10.1210/jc.2017-00469)

Tharakan G, Behary P, Wewer Albrechtsen NJ, Chahal H, Kenkre J, Miras AD, Ahmed AR, Holst JJ, Bloom SR \& Tan T 2017 Roles of increased glycaemic variability, GLP-1 and glucagon in hypoglycaemia after Roux-en-Y gastric bypass. European Journal of Endocrinology 177 455-464. (https://doi.org/10.1530/EJE-17-0446)

Thondam SK, Daousi C, Wilding JP, Holst JJ, Ameen GI, Yang C, Whitmore C, Mora S \& Cuthbertson DJ 2017 Glucose-dependent insulinotropic polypeptide promotes lipid deposition in subcutaneous adipocytes in obese type 2 diabetes patients: a maladaptive response. American Journal of Physiology: Endocrinology and Metabolism $\mathbf{3 1 2}$ E224-E233. (https://doi.org/10.1152/ajpendo.00347.2016)

Tillner J, Posch MG, Wagner F, Teichert L, Hijazi Y, Einig C, Keil S, Haack T, Wagner M, Bossart M, et al. 2019 A novel dual glucagonlike peptide and glucagon receptor agonist SAR425899: results of randomized, placebo-controlled first-in-human and first-in-patient trials. Diabetes, Obesity and Metabolism 21 120-128. (https://doi. org/10.1111/dom.13494) https://joe.bioscientifica.com https://doi.org/10.1530/JOE-20-0119
(C) 2020 Society for Endocrinology Published by Bioscientifica Ltd. Printed in Great Britain 
Tschop MH, Finan B, Clemmensen C, Gelfanov V, Perez-Tilve D, Muller TD \& DiMarchi RD 2016 Unimolecular polypharmacy for treatment of diabetes and obesity. Cell Metabolism 24 51-62. (https:// doi.org/10.1016/j.cmet.2016.06.021)

Wadden TA, Hollander P, Klein S, Niswender K, Woo V \& Hale PM, Aronne L \& NN8022-1923 Investigators 2013 Weight maintenance and additional weight loss with liraglutide after low-caloriediet-induced weight loss: the SCALE maintenance randomized study. International Journal of Obesity 37 1443-1451. (https://doi. org/10.1038/ijo.2013.120)
World Health Organisation 2000 Obesity: preventing and managing the global epidemic. Report of a WHO consultation. World Health Organization Technical Report Series 894 i-xii, 1-253. (available at: https://www.who.int/nutrition/publications/obesity/ WHO_TRS_894/en/)

Wynne K, Park AJ, Small CJ, Meeran K, Ghatei MA, Frost GS \& Bloom SR 2006 Oxyntomodulin increases energy expenditure in addition to decreasing energy intake in overweight and obese humans: a randomised controlled trial. International Journal of Obesity $\mathbf{3 0}$ 1729-1736. (https://doi.org/10.1038/sj.ijo.0803344)

Received in final form 13 May 2020

Accepted 19 May 2020

Accepted Manuscript published online 21 May 2020 (c) 2020 Society for Endocrinology Published by Bioscientifica Ltd. Printed in Great Britain 